The Non-Status Indian Population Living Off-Reserve in Canada: A Demographic and Socio-Economic Profile

\author{
Andrew J. Siggner \\ Director, Siggner \& Associates, Inc. \\ Evelyn J. Peters \\ Urban and Inner City Studies, University of Winnipeg
}

aboriginal policy studies Vol. 3, no. 3, 2014, pp. 86-108

This article can be found at:

http://ejournals.library.ualberta.ca/index.php/aps/article/view/18582

ISSN: 1923-3299

Article DOI: http://dx.doi.org/10.5663/aps.v3i3.18582

aboriginal policy studies is an online, peer-reviewed and multidisciplinary journal that publishes original, scholarly, and policy-relevant research on issues relevant to Métis, non-status Indians and urban Aboriginal people in Canada. For more information, please contact us at apsjournal@ualberta.ca or visit our website at www.ualberta.ca/nativestudies/aps/. 


\title{
The Non-Status Indian Population Living Off-Reserve in Canada: A Demographic and Socio-Economic Profile
}

\author{
Andrew J. Siggner \\ Director, Siggner \& Associates, Inc. \\ Evelyn J. Peters \\ Urban and Inner City Studies, University of Winnipeg

\section{Introduction}

A variety of processes including the history of treaty making, changing legislative definitions of Aboriginal groups, administrative record keeping, and the design of census questions have led to a complex categorization system of Aboriginal peoples in Canada. More recently, shifts in either the meaning of categories (Andersen 2008) or patterns of self-identification (Guimond et al.2009) have altered the altered the size and characteristics of the population in different categories. This paper explores the demographic and socioeconomic characteristics of one administrative category of Aboriginal people in Canada, those defined as Non-Status Indians.

The category of "Non-Status Indian" emerged from the combination of definitional acts by the Canadian federal government. "Aboriginal," the collective term most often used to refer to Indigenous peoples in Canada at this time, obscures tremendous cultural, historical, and legal complexity. The Constitution Act, 1982, identified three groups of Aboriginal people: the North American Indians (most often called "First Nations"); the Métis, who are descendants of Europeans and First Nations people and who established a unique cultural and political regime in western Canada; and the northern Inuit peoples. ${ }^{1}$ Adding to this complexity is an additional category created by the Indian Act of Canada, first introduced in $1850^{2}$ and subject to many subsequent amendments. While the first Indian Acts did not define who was an "Indian," the Indian Act began, in 1869, to lay out regulations for determining who was "Indian" and, by definition, who had lost that status. Definitions varied as the Indian Act was amended again and again. Currently, NonStatus Indians are individuals who identify themselves, culturally, as First Nations people (or North American Indians, which is the term used in the census) rather than as Métis or Inuit, but they are not registered under the Indian Act.

1 There are many distinct cultures within these larger groupings. Using linguistic groupings as one measure of cultural differences, there are more than fifty distinct language groups among First Nations peoples, there are several Inuktitut dialects among the Inuit, and the Métis speak a variety of First Nations languages as well as Michif, which evolved out of their First Nations and European ancestry (Royal Commission on Aboriginal Peoples [RCAP] 1996, 11).

2 These early Indian Acts were found in both Upper and Lower Canada.

aboriginal policy studies, vol. 3, no. 3, 2014 
There have been many processes, historically, leading to the creation of a category of individuals who, while identifying themselves culturally as First Nations, are not registered under the Indian Act. The most well-known process has to do with clauses introduced in 1869 amendments to the Indian Act that stated that First Nations women who married non-First Nations men would lose their status, and that all of the children from those marriages also would not have Registered Indian status. As noted below, Bill C-31 amended the Indian Act of Canada in 1985 to allow individuals who had lost legal Indian status in this way to apply to regain status. However, many individuals have not taken this route, either by choice or because of impediments in the application process. Registered Indians have also, at various times and with different amendments to the Indian Act, lost or given up their status when they joined various professions, served in the army, lived in another country, wanted to vote, or wanted to buy land. In 1951, the process of creating a centralized registry from the lists held by Indian agents on individual reserves resulted in some families and individuals being left out or removed from the rolls. Finally, there are some groups who consider themselves First Nations, but who never signed a treaty and so are not considered as First Nations people by the federal government. ${ }^{3}$ While this is a partial list, it does describe the major routes individuals have taken to fall into the category "Non-Status Indian."

There is almost no work that focuses on the demographic and socio-economic characteristics of this category of Aboriginal peoples. Most often, they are included in an analysis of the larger Aboriginal population, or in work on First Nations peoples. However, there are some differences between Non-Status Indians and Registered Indians, Inuit, and Métis people as a group that may lead them to possess different characteristics. The differences are simplest to describe when they refer to legal definitions that lie at the basis of government programming. Non-Status Indians do not have access to programs and services available through the federal government to Registered Indians. For example, they do not have the legal right to live on reserve once they become adults, ${ }^{4}$ they cannot vote in band elections or run for positions on band councils, and they do not have access to those few services delivered by the federal government to Status Indians living off reserves. They also do not have access to federal programs or services available to Inuit people. When the distinctions occur on the basis of self-identification, differences are more difficult to delineate. The Métis National Council (MNC), represented in BC, Saskatchewan, Manitoba, and Ontario, states: "Métis means a person who self-identifies as Métis, is of historic Métis nation ancestry, is distinct from other Aboriginal peoples and is accepted by the Métis nation" (Gionet 2009). It seems likely that, in these provinces, individuals who viewed themselves as Aboriginal, but were not Registered Indians or Inuit and did not have links to the history of the Métis Nation, would identify as Non-Status Indian. In other parts

3 See, for example, the Lubicon Cree Nation in northern Alberta: http://www.lubiconlakenation.com/.

4 Currently, some parents cannot pass on their Indian status to their children because of the history of intermarriage that resulted in their own status category. Children from these parents have the legal right to live on the reserve until they become adults. 
of the country, however, individuals whose ancestry includes both Aboriginal and NonAboriginal people identify as Métis (Laliberte forthcoming). An analysis of the complex processes leading to differences in self-identification is beyond the scope of this paper. Differences between the various Aboriginal categories, however, suggest that it is useful to explore the demographic and socio-economic characteristics of Non-Status Indians.

\section{Method}

The Canadian census is a survey, conducted every five years, of all persons living in Canada. Beginning in 1996, the Canadian census began to ask individuals who reported Aboriginal ancestry whether they "identified" with their reported ancestry. The "identity population" (those who identified as a North American Indian, Métis, or Inuit person) was considered to more accurately capture the meaning of what had been termed a "core Aboriginal population" (Goldmann and Siggner 1995). The question was meant to provide an "indicator of an individual's feelings, allegiance or association" with Aboriginal culture (Goldmann 1993, 11).

Currently, the Canadian census includes several questions to enumerate Aboriginal populations:

Q 18. Is this person an Aboriginal person, that is, North American Indian, Métis or Inuit (Eskimo)?

Q 20. Is this person a member of an Indian Band / First Nation? (If the answer is "yes," respondents are asked to write in name of band or First Nation.)

Q 21. Is this person a Treaty Indian or a Registered Indian as defined by the Indian Act of Canada? (UN, no date).

These questions allow us to derive the Non-Status Indian population used in the following analysis. Respondents who answered that they were "North American Indian," and then also reported on the Registered Indian question that they did not have Registered Indian status according to the Indian Act of Canada were derived as Non-Status Indians.

The data used in this paper comes from the 1996, 2001, and 2006 long-form census, which was a one-in-five household sample. Data from the 2011 census is not yet available. This long-form questionnaire, which was mandatory for respondents to fill out at the time, asked a large number of additional demographic, cultural, social, economic, and housing questions. Except for the first section below, the data refer to those persons not living on Indian reserves or Crown land settlements (administered as Indian reserves).

\section{Size and Growth of the Non-Status Indian Population}

Table 1 lists four different Aboriginal groups in Canada and gives their total population size in 2006, including individuals living on reserves. ${ }^{5}$ Non-Status Indians represented the third largest category of the Aboriginal population in 2006. Registered Indians represented

5 The size of the Registered Indian population is likely larger: for several census periods, a number of reserves have refused to participate in census-taking. As a result, the number and proportion of Registered Indians living on reserves are underestimated (Norris and Clatworthy 2003, 54). 
the majority of Aboriginal people, comprising slightly over half (52.1\%). Métis people were next, at slightly less than one third (32.6\%). Non-Status Indians comprised slightly more than one tenth of the population at 11.1 percent, and Inuit people represented 4.2 percent of the Canadian Aboriginal population.

TABLE 1: Size of the Total Non-Status Indian Population Compared to Other Aboriginal Categories, 2006

\begin{tabular}{|l|c|c|}
\hline & Population Size & \% of Total Population \\
\hline $\begin{array}{l}\text { Total Aboriginal } \\
\text { Population }\end{array}$ & $1,172,790$ & 11.1 \\
\hline Non-Status Indian & 133,155 & 52.1 \\
\hline Registered Indian* & 623,780 & 32.6 \\
\hline Métis & 389,780 & 4.2 \\
\hline Inuit & 50,485 & \\
\hline $\begin{array}{l}\text { *Unadjusted for incompletely enumerated reserves } \\
\text { ***The total for the individual population categories adds up to more than the total } \\
\text { Aboriginal population because some individuals identified with more than one } \\
\text { category. Percentages are calculated using the total of the individual Aboriginal } \\
\text { population categories. }\end{array}$ \\
\hline
\end{tabular}

Similar to other categories of the Aboriginal population, the Non-Status Indian population has experienced extremely rapid growth in recent decades. Table 2 describes this in terms of absolute population growth.

TABLE 2: Absolute and Proportionate Population Increase, Non-Status Indian Compared to Other Aboriginal Categories, 1996-2006

\begin{tabular}{|l|c|c|}
\hline & $\begin{array}{c}\text { Absolute Increase, } \\
\text { 1996-2006 }\end{array}$ & $\begin{array}{c}\text { Proportionate Increase, } \\
\text { 1996-2006 }\end{array}$ \\
\hline $\begin{array}{l}\text { Total Aboriginal } \\
\text { Population }\end{array}$ & 373,780 & $\mathbf{4 7 \%}$ \\
\hline Non-Status Indian & 46,560 & $28 \%$ \\
\hline Registered Indian* & 135,740 & $91 \%$ \\
\hline Métis & 185,665 & $26 \%$ \\
\hline Inuit & 10,260 & \\
\hline *Unadjusted for incompletely enumerated reserves & \\
\hline
\end{tabular}


Between 1996 and 2006, the total Aboriginal population in Canada increased by 373,780: a 47 percent growth rate. In comparison, the non-Aboriginal population grew by 8 percent during that same ten-year time period. There are typically three sources of demographic growth for any population living in a specific country: fertility, mortality, and net international migration (due to the difference of those entering the country and those leaving it). The latter has had a negligible effect on the growth of Aboriginal people in Canada. While fertility rates are higher in the Aboriginal than in the non-Aboriginal population, and Aboriginal mortality rates have been declining, demographers argue that most of the recent Aboriginal growth rates can be explained by factors other than demographic sources.

Some of the growth in the total Aboriginal and the Registered Indian populations may be related to legislation passed in 1985, which allowed for the reinstatement of First Nations people who had lost their legal Indian status through a variety of processes. The reinstatement process itself has been stretched out over time. However, demographers have argued that a large part of the population increase of the last two decades comes from individuals who did not identify as Aboriginal in previous census years, but who were now choosing to do so (Guimond 2003). Researchers have documented a similar phenomenon in the US, identifying US ethnic politics that embraced ethnic pride and Indian activism (Nagel 1995) as contributing factors in that choice. Siggner (2003) has suggested that shifting attitudes toward Aboriginal peoples in Canada were important in changing patterns of self-identification during this time. In his analysis of the changing meaning of "Métis" in the Canadian census, Andersen (2008) argued that this process was related to changes in the meaning and significance of the categories themselves, rather than to changes in identity.

The finding that the Non-Status Indian population increased by 54 percent (from 86,595 to 133,155 people) between 1996 and 2006 is surprising. From a demographic perspective, we would expect that 1985 legislation would have the effect of reducing the size of the NonStatus Indian population, as these individuals applied for and were granted reinstatement of legal Indian status. Despite this loss, the Non-Status Indian population grew. There has not been any analysis of the components of growth (fertility, mortality, changes in identity, or the meaning of the category) for the Non-Status Indian population. Analysis for other categories, however, suggests that changes in self-identification, or the meaning of the category "Non-Status Indian," represent the main contributor to population growth. While we do not fully understand the processes through which this occurs, there are some interesting policy implications in that there is a growing population of individuals who do not have Registered Indian status and do not see themselves as Métis. Who represents these populations, politically? What are their Aboriginal rights? What will be their future demands, especially since section 35 of the Canadian constitution, which guarantees rights of the Aboriginal peoples of Canada, refers to "Indians" and does not differentiate between those who are registered and those who are not? 
The uneven distribution of Non-Status Indians across the country and variations in rates of change mean that some regions and provinces will be more affected by the growth of this population than others. The distribution of Non-Status Indians follows that of the total Aboriginal population to some extent, but there are also variations (see Table 3).

TABLE 3: Distribution of the Non-Status Indian Population (2006) and Growth (20012006)

\begin{tabular}{|c|c|c|c|}
\hline & $\begin{array}{c}\% \text { of Total Aboriginal } \\
\text { Population in } \\
\text { Province or Territory }\end{array}$ & $\begin{array}{l}\% \text { of Total Non-Status } \\
\text { Indian Population in } \\
\text { Province or Territory }\end{array}$ & $\begin{array}{l}\text { \% Increase in Non- } \\
\text { Status Indian } \\
\text { Population, } \\
2001-2006\end{array}$ \\
\hline Ontario & 20.7 & 36.9 & 36.4 \\
\hline British Columbia & 16.7 & 21.7 & 15.3 \\
\hline Alberta & 16.1 & 11.0 & 16.6 \\
\hline Manitoba & 15.0 & 4.3 & -9.0 \\
\hline Saskatchewan & 12.1 & 3.4 & 0.9 \\
\hline Quebec & 9.2 & 13.3 & 114.1 \\
\hline Nunavut & 2.1 & 0.0 & 133.3 \\
\hline Nova Scotia & 2.0 & 3.2 & 41.2 \\
\hline Newfoundland/Labrador & 1.9 & 2.6 & -25.2 \\
\hline Northwest Territory & 1.8 & 0.5 & 58.3 \\
\hline New Brunswick & 1.4 & 2.1 & 21.5 \\
\hline Prince Edward Island & 1.4 & 1.4 & 74.5 \\
\hline Yukon Territory & 0.6 & 0.6 & -1.2 \\
\hline
\end{tabular}

Most Aboriginal people and most Non-Status Indians live in the Prairie provinces, Ontario, Quebec, and British Columbia. Relatively few live in the Maritimes or in the Territories. Compared to the total Aboriginal population distribution across Canada, NonStatus Indians are over-represented in British Columbia, Ontario, and Quebec, and underrepresented in Alberta, Saskatchewan, and Manitoba. No research has been conducted to explore the dynamics of identification as Métis rather than Non-Status Indian, but NonStatus Indians tend to be under-represented in the Prairie provinces, where the Métis Nation and Métis identities have the longest history. Clearly any interpretation is speculative, but the pattern generates a question about whether Non-Status Indians are more likely to see 
themselves under the Métis (rather than the Non-Status Indian) category in the Prairie provinces. Or, perhaps applications for Indian status reinstatement are, for some reason, more likely to be successful in these provinces.

The proportionate increase of the Non-Status Indian population also varies by province. We will not analyze the data for the Maritime provinces and the Territories: Aboriginal populations there are small and, as a result, any small increases result in large proportionate increases in the Non-Status Indian population. In the remaining provinces, Quebec (114.1\%) and Ontario (36.4\%) had the largest increases of Non-Status Indians between 1996 and 2006, followed by Alberta (16.6) and British Columbia (15.3\%). In contrast, Manitoba experienced a loss of Non-Status Indians (9.0\%), while Saskatchewan's Non-Status Indian population remained almost the same $(0.9 \%)$. It is difficult to interpret these statistics with any degree of certainty, but one thing that is clear is that different regions will experience the implications of changing Non-Status Indian populations differently.

\section{Socio-Economic Characteristics of Non-Status Indians Compared to the Total Aboriginal Population Living Off-Reserve}

While we do not have a good grasp of what cultural and identity characteristics differentiate Non-Status Indians from Registered Indians and Métis people, it is established that Non-Status Indians have different legal rights, and, at least for some individuals, differing histories. This leads to questions about how Non-Status Indians compare to the total Aboriginal population living off reserves.

FIGURE 1: Aboriginal Category by Area of Residence, Canada, 2006 Census

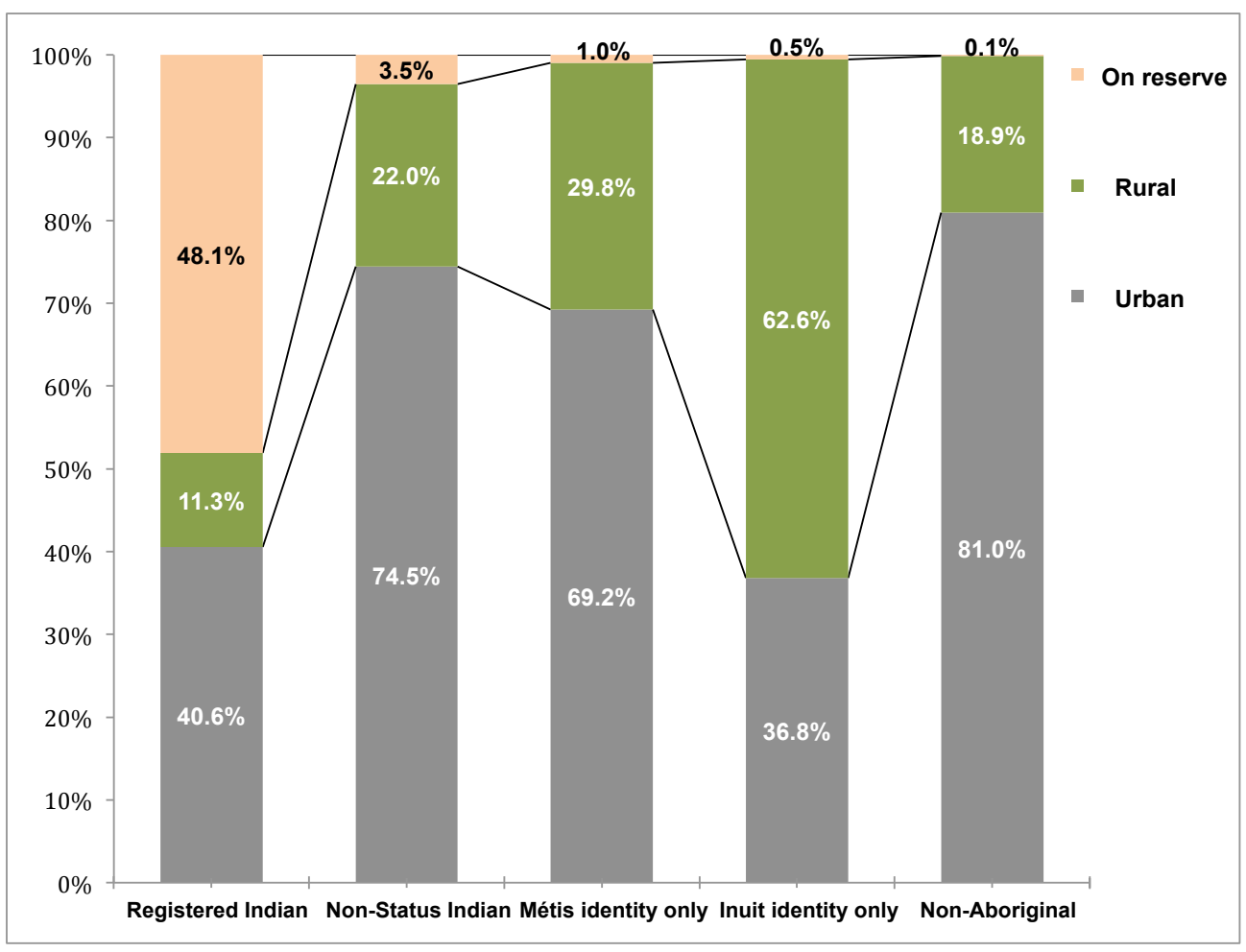


Non-Status Indians are the most likely of all categories of Aboriginal people to live in the city. In 2006, nearly 75 percent Non-Status Indians lived in cities, compared to 69 percent of Métis, 40 percent of Registered Indians, and about 37 percent of Inuit (see Figure 1). By comparison, 81 percent of Non-Aboriginal people resided in urban areas in Canada in 2006. Slightly more than one-fifth (22\%) of Non-Status Indian people lived in rural nonreserve areas, and only 3.5 percent lived on reserves. This means that the implications of increasing Non-Status Indian populations will be found mostly in urban areas.

Table 4 compares selected socio-economic characteristics of Non-Status and the total Aboriginal population living off the reserve for 2006.

TABLE 4: Comparison of Selected Characteristics, Non-Status Indians and Total Aboriginal Population Off-Reserve, 2006

\begin{tabular}{|c|c|c|}
\hline & $\begin{array}{c}\text { Total Non-Status Indian, } \\
\text { Off-Reserve }\end{array}$ & $\begin{array}{l}\text { Total Aboriginal, } \\
\text { Off-Reserve }\end{array}$ \\
\hline Under 15 years old & $28.3 \%$ & $31.4 \%$ \\
\hline Under 25 years old & $46.2 \%$ & $48.4 \%$ \\
\hline Age 65 and older & $4.8 \%$ & $5.0 \%$ \\
\hline Lived at the same address one ye & $77.1 \%$ & $77.3 \%$ \\
\hline Age 15-19, not attending school & $26.6 \%$ & $25.8 \%$ \\
\hline Age 20-34 with university certific & $32.7 \%$ & $27.6 \%$ \\
\hline Employment rate & $58.0 \%$ & $59.0 \%$ \\
\hline Income from employment & $78.4 \%$ & $77.3 \%$ \\
\hline Income from government transfer & $16.1 \%$ & $16.1 \%$ \\
\hline Other income & $5.5 \%$ & $6.6 \%$ \\
\hline Median income & $\$ 19,051$ & $\$ 18,969$ \\
\hline Households that are lone parent & $14.3 \%$ & $11.5 \%$ \\
\hline Owned dwellings & $54.6 \%$ & $55.0 \%$ \\
\hline Dwelling requiring major repairs & $14.1 \%$ & $14.3 \%$ \\
\hline
\end{tabular}


The data shows that these two populations have very similar characteristics. Both have a large proportion of their population that are under 15 years of age, and the population aged 65 and older is about 5 percent for both groups. More than three-quarters were living in the same residence as they were the previous year. Slightly more than one-quarter of the youth between 15 and 19 years old were not attending school. A slightly higher proportion of the total Aboriginal population living off-reserve (32.7\%) than the Non-Status Indian population $(27.6 \%)$ in the $20-34$ age bracket had a university certificate or degree. Employment rates were almost identical to the total Aboriginal and Non-Status Indian population employed (58\% and 59\%, respectively). Most individuals in both categories obtained most of their income from employment, and a similar minority obtained their income from government transfer payments and other sources of income. The median income of the total Aboriginal population living off-reserve is only very slightly higher (a difference of \$82) than that of the Non-Status Indian population living off- reserve. NonStatus Indian households are slightly less likely than the total Aboriginal population to be led by single parents ( $11.5 \%$ and $14.3 \%$ respectively). About the same proportion, slightly more than half, own the dwelling units they are in, and about the same proportion (slightly over 14\%) of dwelling units they live in require major repairs.

The lack of difference in socio-economic status between the Non-Status Indian and total Aboriginal population is interesting. Non-Status Indians' socio-economic characteristics are almost identical to the total Aboriginal population living off-reserve. What are the mechanisms that create these similarities, despite differences in legal standing, place of residence, and (arguably) cultures and histories? These are questions that need further research.

\section{Socio-Economic Characteristics of Non-Status Indians Compared to Non-Aboriginal People Living Off-Reserve}

The socio-economic differences between Non-Status Indian and the non-Aboriginal population are greater than differences between Non-Status Indians and the total Aboriginal population.

Age

The Non-Status Indians population is much younger than the non-Aboriginal population. In 2006, 31.4 percent of Non-Status Indians living off reserves were under 15 years old, compared to 17.4 percent of non-Aboriginal people living off-reserve (Siggner 2012).

\section{Mobility}

While Non-Status Indians are more geographically mobile than the non-Aboriginal population, the differences between the two populations decreased over time as NonStatus Indians became less geographically mobile (Figure 2). In 1996, just under 70 percent 
of Non-Status Indians did not change dwellings from the previous year. By 2006, just over 77 percent did not move dwellings. In contrast, non-Aboriginal mobility rates stayed relatively stable, with 84.9 percent not moving in 1996 and 86 percent in 2006. For the NonStatus Indian population, those changing dwellings within the same community (CSD) in a year declined from 19 percent in 1996 to 14 percent by 2006. A similar downward trend is observed for those changing and/or moving communities, where 11 percent changed communities within a year in 1996, while only 8 percent did so by 2006.

FIGURE 2: One-Year Mobility Status, Non-Status Indian \& Non-Aboriginal Populations

Off-Reserve, 1996, 2001, and 2006

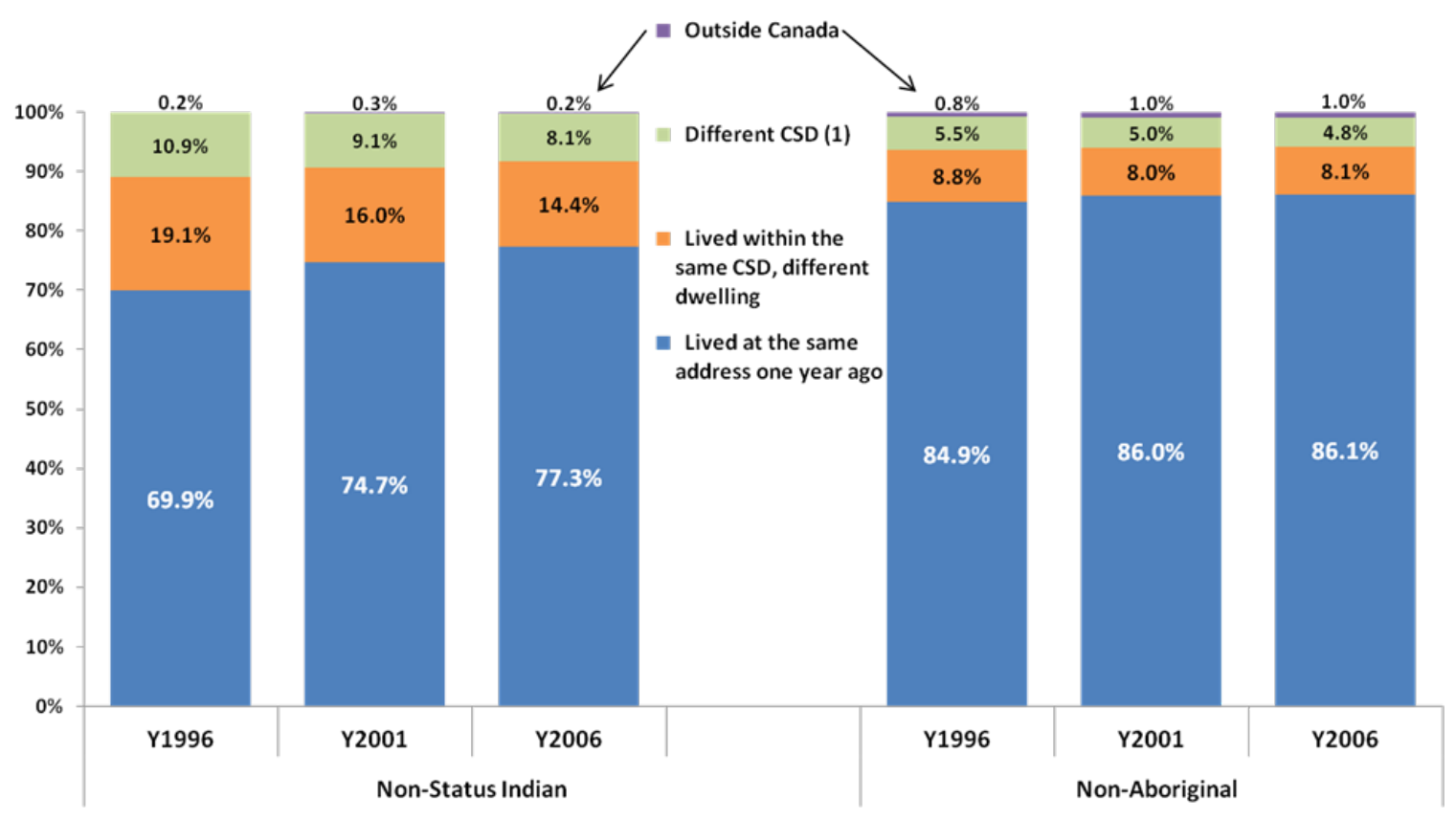

\section{Education}

Despite a slight increase between 1996 and 2001, the percentage of Non-Status Indian teenagers between 15 and 19 decreased slightly between 1996 and 2006 (Figure 3). The pattern of an increase between 1996 and 2001, followed by a decrease in 2006, is also evident in the non-Aboriginal population. The census question on education changed between the 2001 and 2006 census, so it is difficult to interpret these patterns as a trend. What is clear, though, is that Non-Status Indian teenagers are quite a bit more likely to be out of school than non-Aboriginal teenagers. 
FIGURE 3: Percentage of Non-Status Indians and Non-Aboriginal People Aged 15-19 Out of School, Off-Reserve, Canada, 1996-2006*

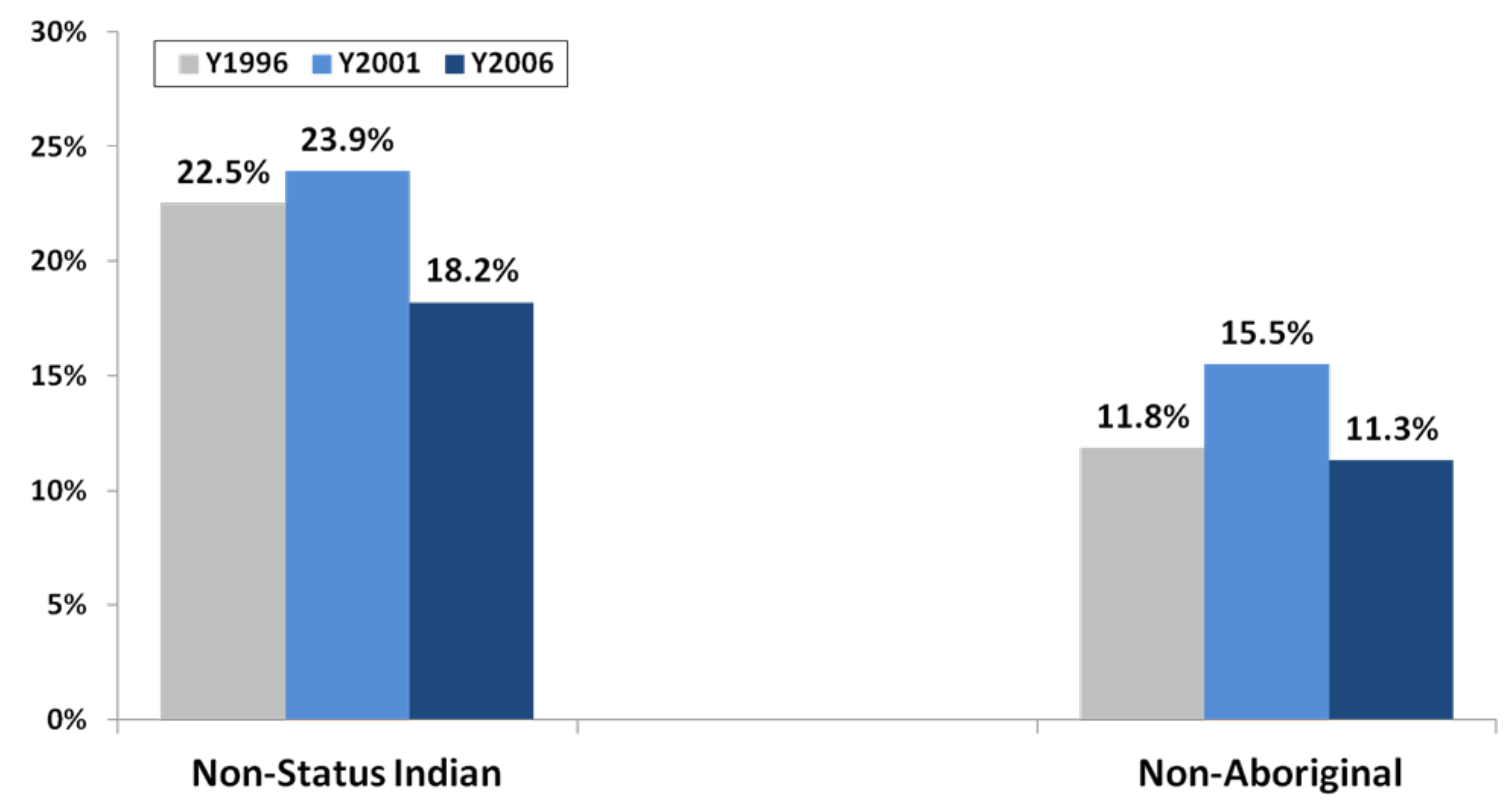

*There was a change to the wording of the census question on education in 2006, so percentages between 2001 and 2006 are not strictly comparable.

The percentage of Non-Status Indians aged 20 to 35 with a university degree increased by 2.3 percent between 1996 and 2006 (Figure 4). At the same time, only 5.6 percent of the Non-Status Indian population had a university degree in 2006, compared to 22.7 percent of the non-Aboriginal population. The proportion of non-Aboriginal people with a university degree increased by 7.1 percent over this period, while the proportion of Non-Status Indians with a university degree increased by only 2.3 percent.

If this trend continues, the gap between Non-Status Indians and the non-Aboriginal population will continue to grow. There is also the possibility that the increase in education levels was created by changes in self-identification on census forms. In a 2003 study, Siggner and Hagey found that individuals in higher socio-economic status groups were disproportionately represented among individuals newly identifying as Aboriginal in the census. If this is true for Non-Status Indians in the 1996 period, it means that some of these gains in education are apparent, rather than real. This is because individuals categorized as Non-Status Indian in 2006 who were not included in the 1996 counts already had already higher levels of schooling. This still makes one ask why these changes are happening, although answers are not readily available. 
FIGURE 4: Percentage of Non-Status Indians and Non-Aboriginal People Aged 20-34, Not Attending School, With a University Degree, Off-Reserve, Canada 1996 - 2006

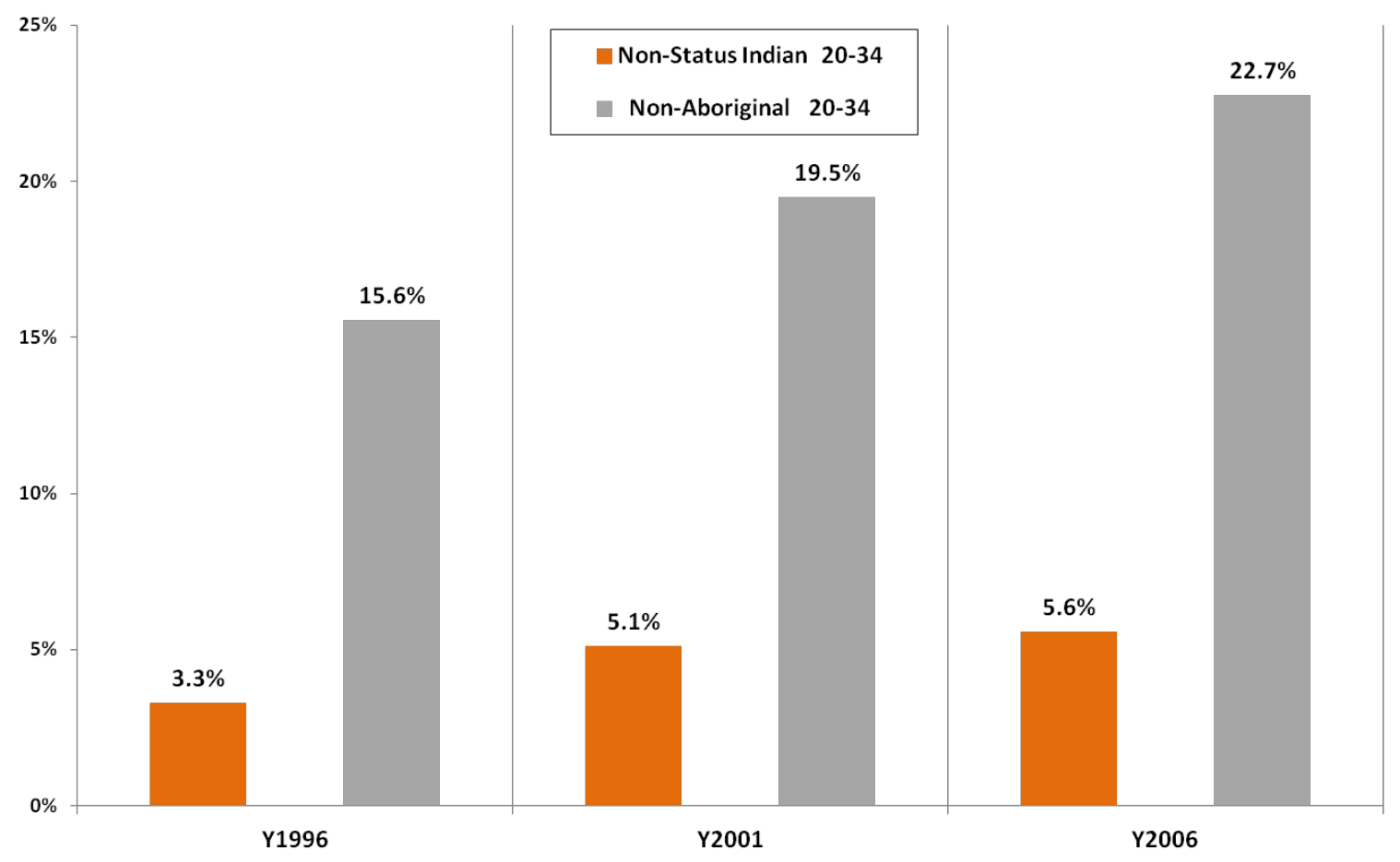

\section{Employment Characteristics}

Figure 5 compares changing employment rates for Non-Status Indians and nonAboriginal people 15 years of age or older, living off-reserve. Employment rates refer to proportion of the population 15 years of age and older who were employed the week before the census. ${ }^{6}$ Non-Status Indian employment rates increased from 52 percent in 1996 to 59 percent by 2006, and were almost on par with their Non-Aboriginal counterpart's 63 percent by $2006 .^{7}$ If this gain is real rather than a result of changing group composition, then it suggests that differences between Non-Status Indians and non-Aboriginal populations decreased during this time period. Non-Aboriginal men had the highest employment rates, followed by Non-Status Indian men (Figure 6). Employment rates for both Non-Status Indian

6 We use this rate rather than the unemployment rate, which is defined as the percentage of the total labour force that is unemployed but actively seeking employment and willing to work, because the latter excludes those who are sometimes called "discouraged workers": those who are unemployed but not looking for work. The distribution of "discouraged workers" is likely not even across different populations, so we feel the employment rates provide a better snapshot of labour force participation.

7 Unfortunately, more current labour force data for the Non-Status Indian population is not available through the Statistics Canada Labour Force Survey, which does ask a question about Aboriginal identity but does not ask about Registered Indian status. 
and non-Aboriginal women were lower than Non-Status Indian and non-Aboriginal men's, and Non-Status Indian women had the lowest employment rates. However, employment rates rose for all categories in the 1996-2006 period. In 2006, the Non-Status Indian female employment rate was a mere two percentage points below the female Non-Aboriginal rate, as compared to a six-point spread at the beginning of the period.

FIGURE 5: Employment Rates for Non-Status Indian and Non-Aboriginal Populations Aged 15+, Off-Reserve, 1996-2006

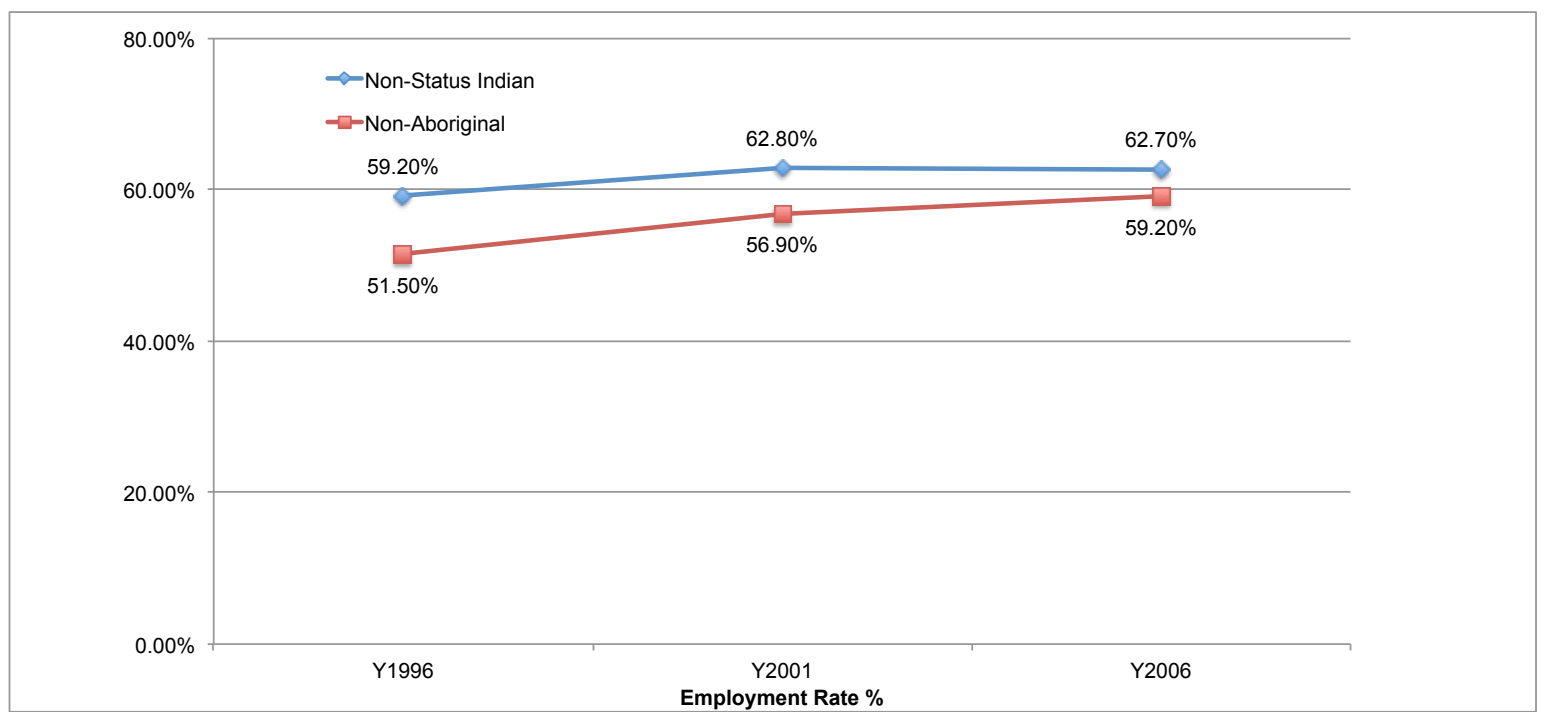

FIGURE 6: Employment Rates for Non-Status Indian and Non-Aboriginal Populations by Gender, Aged 15+, Off-Reserve, 1966-2006

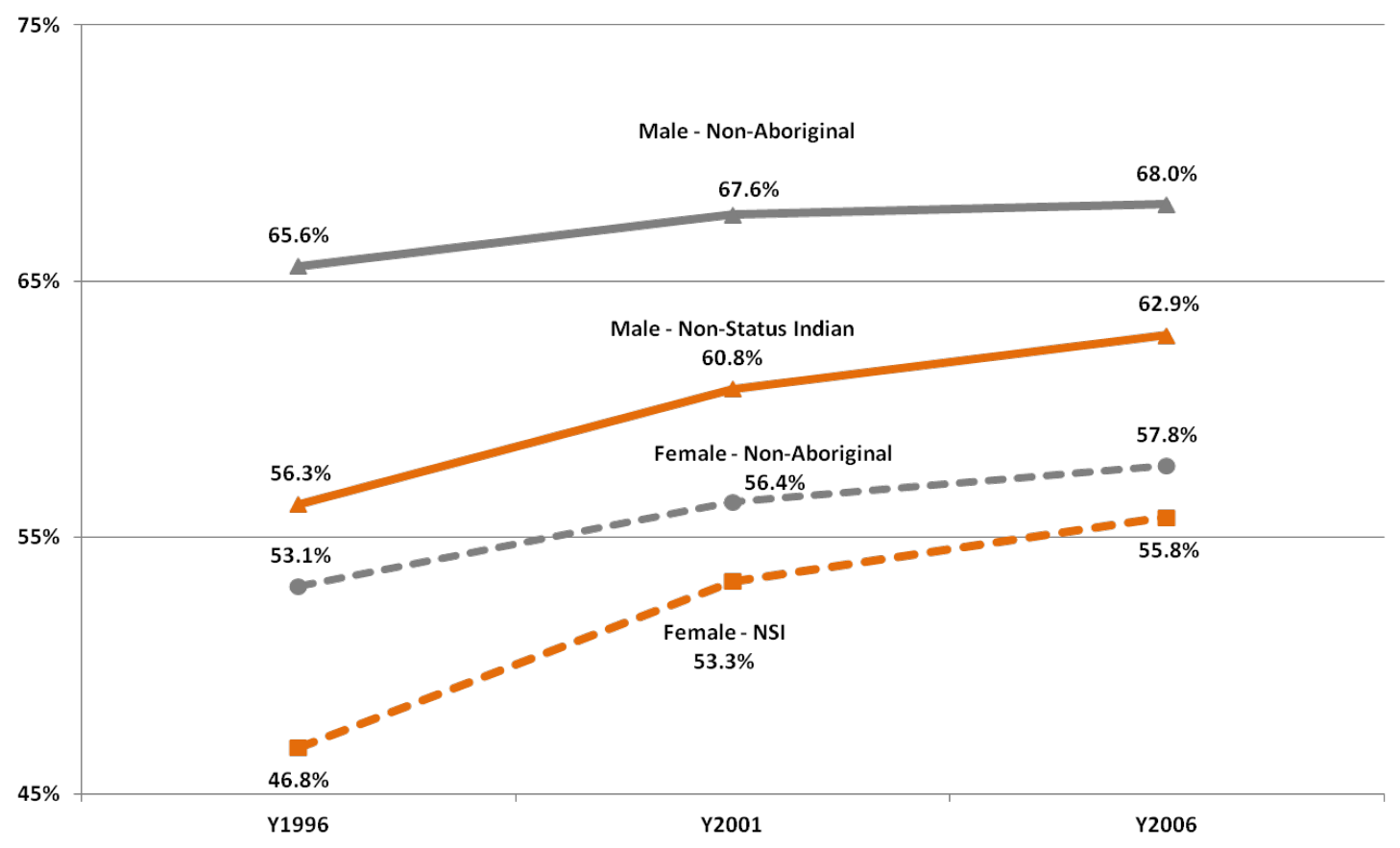


Figures 7 and 8 provide some information about particular aspects of Non-Status Indian labour force participation between 1996 and 2006. In terms of entrepreneurship, there was only a slight rise in the percentage of those Non-Status Indians aged 15 and older who were self-employed, rising from 6.0 to 6.4 percent over the ten-year period (Figure 7).

FIGURE 7: Self-Employment within Non-Status Indian and Non-Aboriginal Populations, Aged 15+, Off-Reserve, 1996-2006

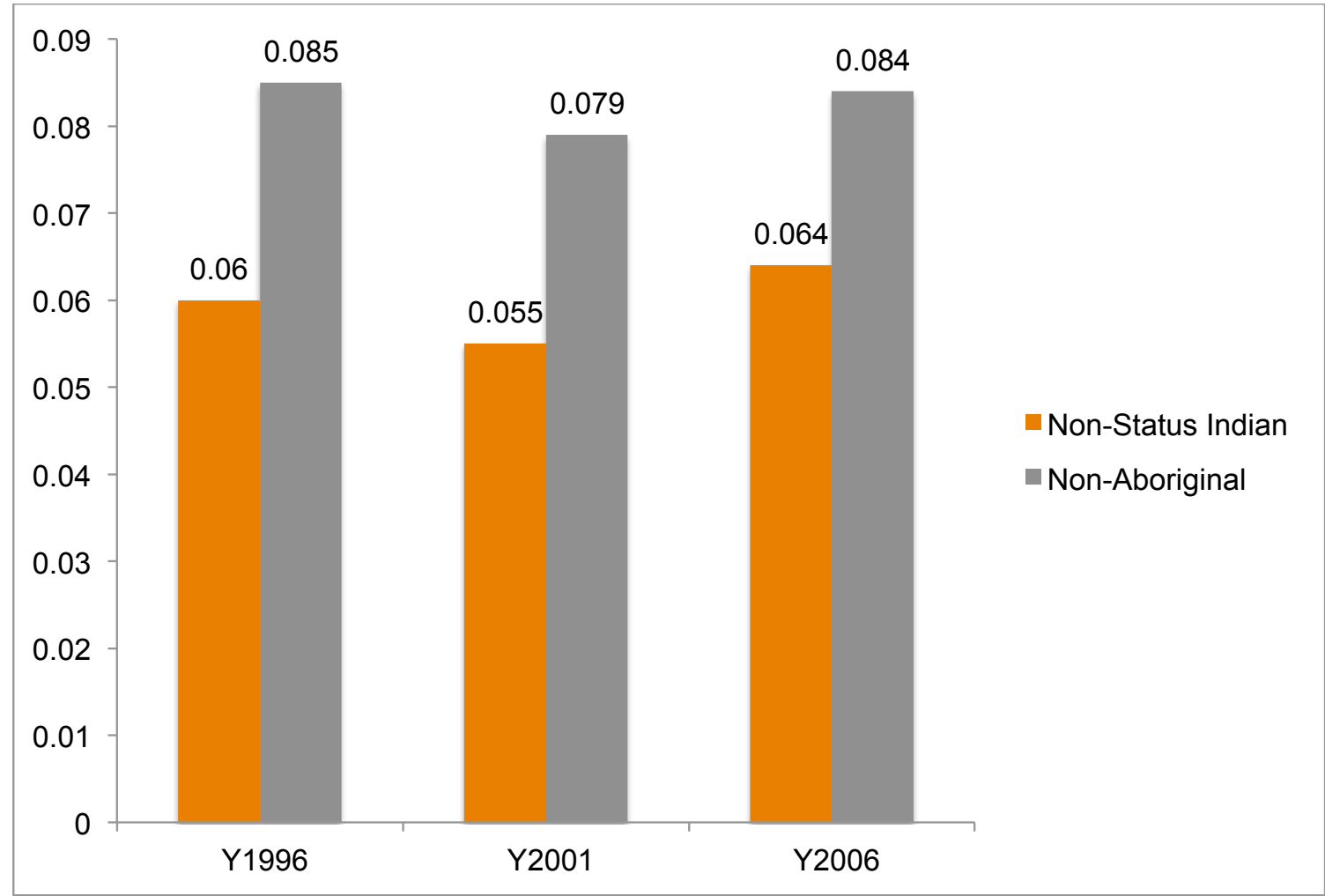

Self-employment constituted only a small proportion $(3.8 \%)$ of the total Non-Status Indian labour force participation in 2006. There is a common perception that selfemployment is a route to upward mobility. If this is the case (and here is not the place to evaluate this perception), Non-Status Indians do not have very much access to this route. Employment in knowledge-based industries generally represents participation in highly skilled and paid work. Non-Status Indians were slightly over-represented in public administration, and in the arts, entertainment, and recreation industries, but underrepresented in all of the other categories (Figure 8). 
FIGURE 8: Percentage of Non-Status Indian and Non-Aboriginal Populations, Aged 15+, Employed in Knowledge-Based Industries, Off-Reserve, 2006

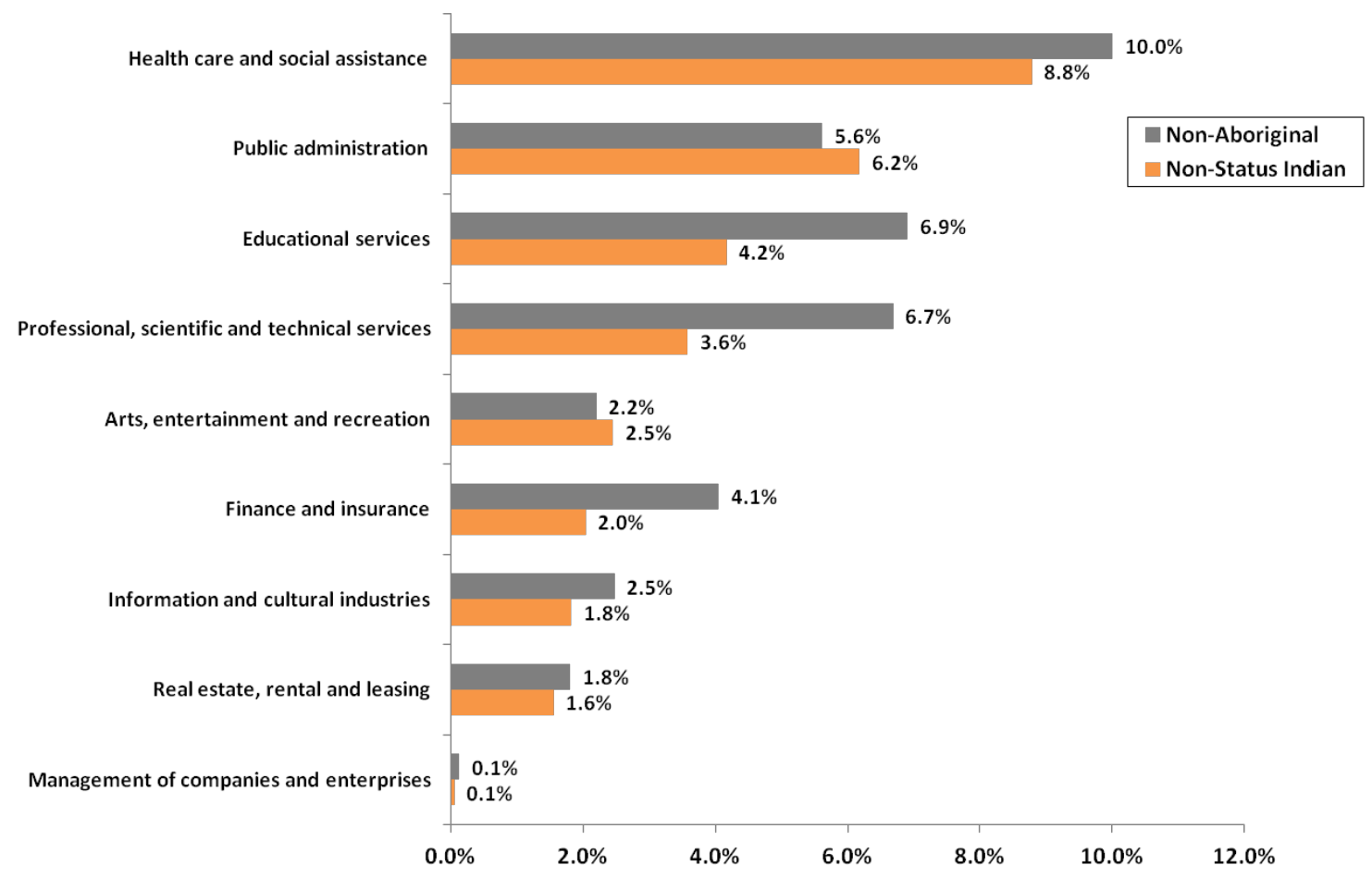

The former may partially reflect employment in urban Aboriginal organizations; the latter may reflect an area where Non-Status Indians can compete without needing the high levels of post-secondary education required in some of the other categories. However, this is speculation; there is little research that explores Aboriginal, let alone Non-Status Indian, participation in knowledge-based economies. Non-Status Indians lagged behind particularly in the professional/scientific/technical services sector and in educational services, as well as finance/insurance services.

In data not shown, the percentage of Non-Status Indians employed who are in the knowledge industries grew from 22 percent in 2001 to 30 percent by 2006: a rise in numbers from 14,530 to 19,400 . The percentage share of the Non-Aboriginal labour force in knowledge-based industries increased from 27 percent, in 2001, to 40 percent by 2006. In other words, the proportion of the population in knowledge industries increased for both population groups, but the increase was slightly larger among non-Aboriginal people.

\section{Income}

In the census data from 1996, 2001, and 2006, about three-quarters of all income that the Non-Status Indian adult population received in the previous year was from employment, and these proportions are very similar to the non-Aboriginal population (Figure 9). The 
share of income from government transfers (e.g., social assistance, employment insurance payments, and so on) for the Non-Status Indian population was 22 percent in 1996, but declined to 16 percent through 2001 and 2006. The non-Aboriginal population was somewhat less likely to receive transfer income: 14 percent received transfer income in 1996, and 11 percent in 2006. Non-Aboriginal people were more likely than Non-Status Indians to receive "other income," such as income from investments.

FIGURE 9: Sources of Income for Non-Status Indian and Non-Aboriginal Populations Aged 15+, Off-Reserve, 1996-2006

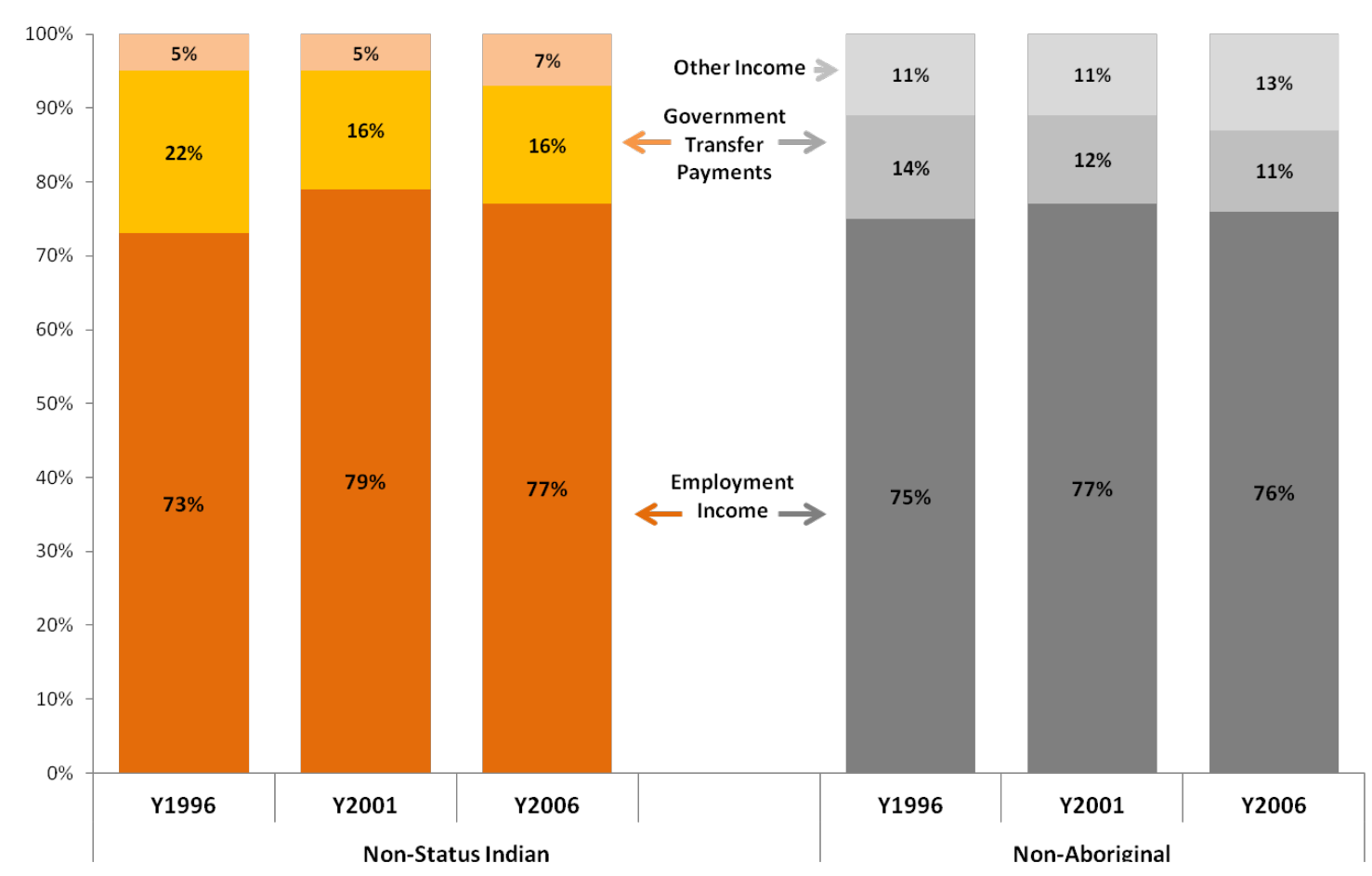

The percentage of the Non-Status Indian population with incomes at or below the Low Income Cut Off (LICO) $)^{8}$ established by Statistics Canada declined from a high of 28 percent in 1996 to 25 percent by 2006 (Figure 10). In contrast, the percentage of non-Aboriginal population at or below the low income level remained at about 15 percent, well below the share of Non-Status Indian population in this income condition.

8 Measures of low-income cut-offs (LICOs) are based on census income data and national family expenditure patterns. They are intended to convey the income level at which a family may be in difficult circumstances because it has to spend a greater proportion of its income on the basics (food, shelter, and clothing) than the average family of similar size. Low-income cut-off points are set according to family size and degree of urbanization. These cut-offs are updated according to changes in the consumer price index. Although LICOs are often referred to as poverty lines, they have no official status as such, and Statistics Canada does not recommend their use for this purpose. 
FIGURE 10: Percent of Economic Family Members and Unattached Individuals At or Below the Low Income Cut-Off, Non-Status Indian and Non-Aboriginal Populations, Off-

Reserve, 1996-2006

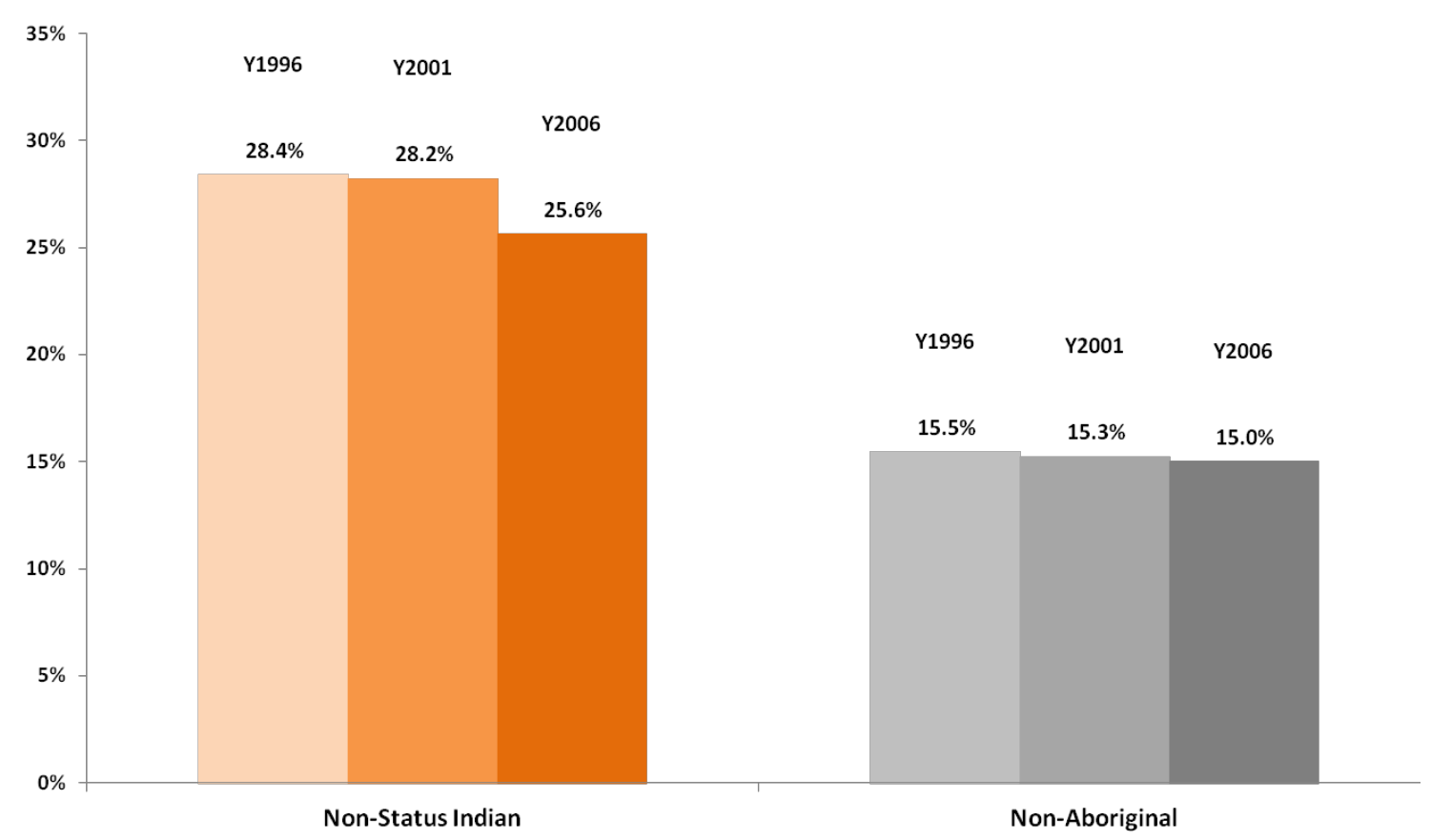

A series of tables demonstrates the effect of education on income. For Non-Status Indians, employment income rises with level of schooling achieved. Table 11 describes median income in relation to education for the total Non-Status Indian population, compared to the non-Aboriginal population. The incomes of both populations rise with education, and the gap between Non-Status Indians and non-Aboriginal people closes at higher levels of education to the extent that Non-Status Indians with a Master's degree have a higher median income than their Non-Aboriginal counterparts. The same incomeeducation pattern occurs among Non-Status Indian adults in the primary working ages of 30 to 44 . After Non-Status Indians have achieved a university certificate or degree, their median employment incomes are better or on par with their Non-Aboriginal counterparts (see Figure 12).

Among Non-Status Indian youth aged 18 to 24, we are actually observing higher median employment incomes than among Non-Aboriginal youth for those with high school completions and trades certificates. For other levels of schooling above trades, incomes are either on par or slightly lower (see Figure 13). These results suggest that increased school retention and strategies to encourage Non-Status Indian individuals to go on to post-secondary education could have major benefits in terms of income levels. 
FIGURE 11: Median Employment Income for the Non-Status Indian and Non-Aboriginal Populations Aged 15-64 by Highest Level of Schooling, Off-Reserve, 2006

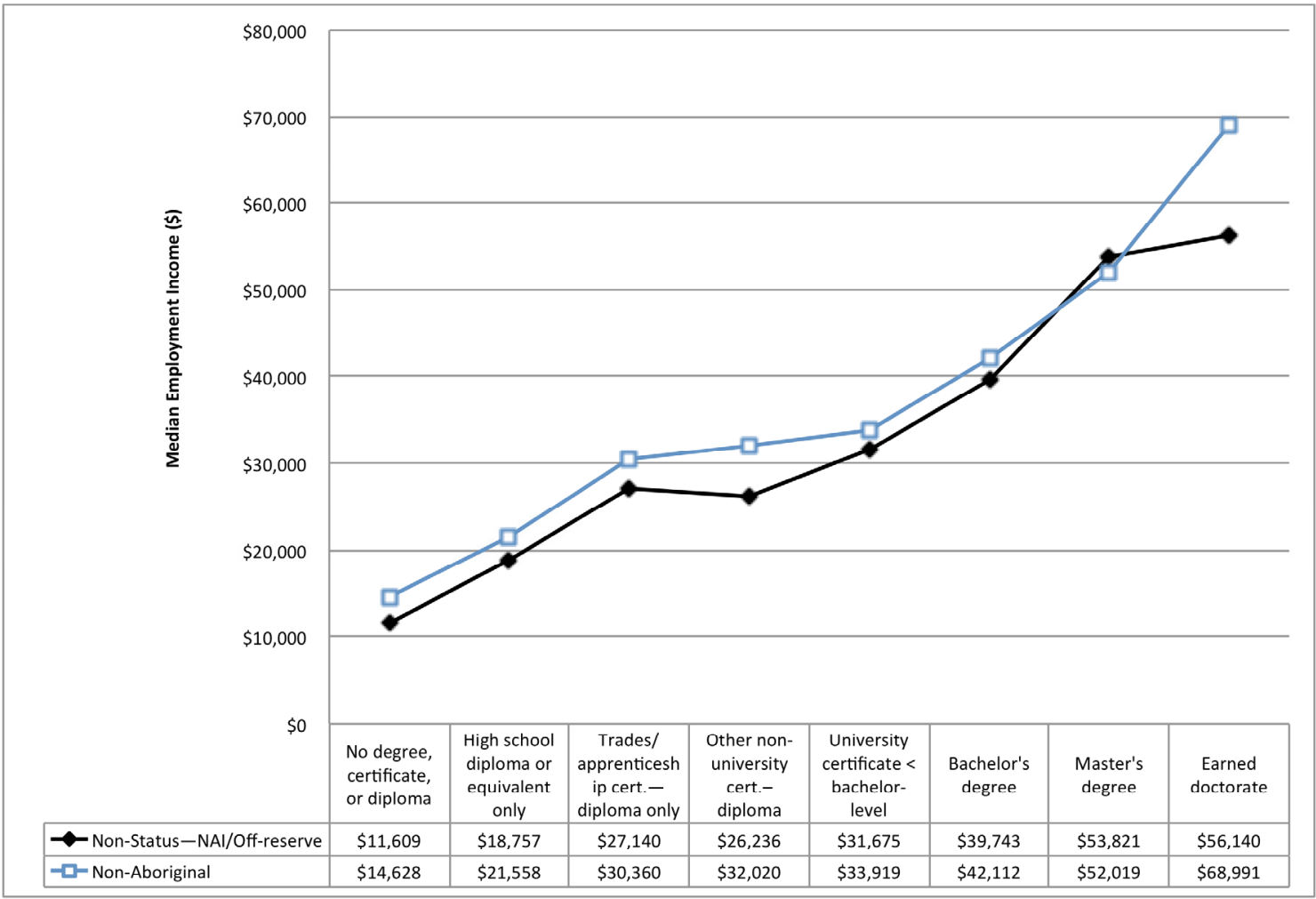

FIGURE 12: Median Employment Income for the Non-Status Indian and Non-Aboriginal Populations Aged 30-44 by Highest Level of Schooling, Off-Reserve, 2006

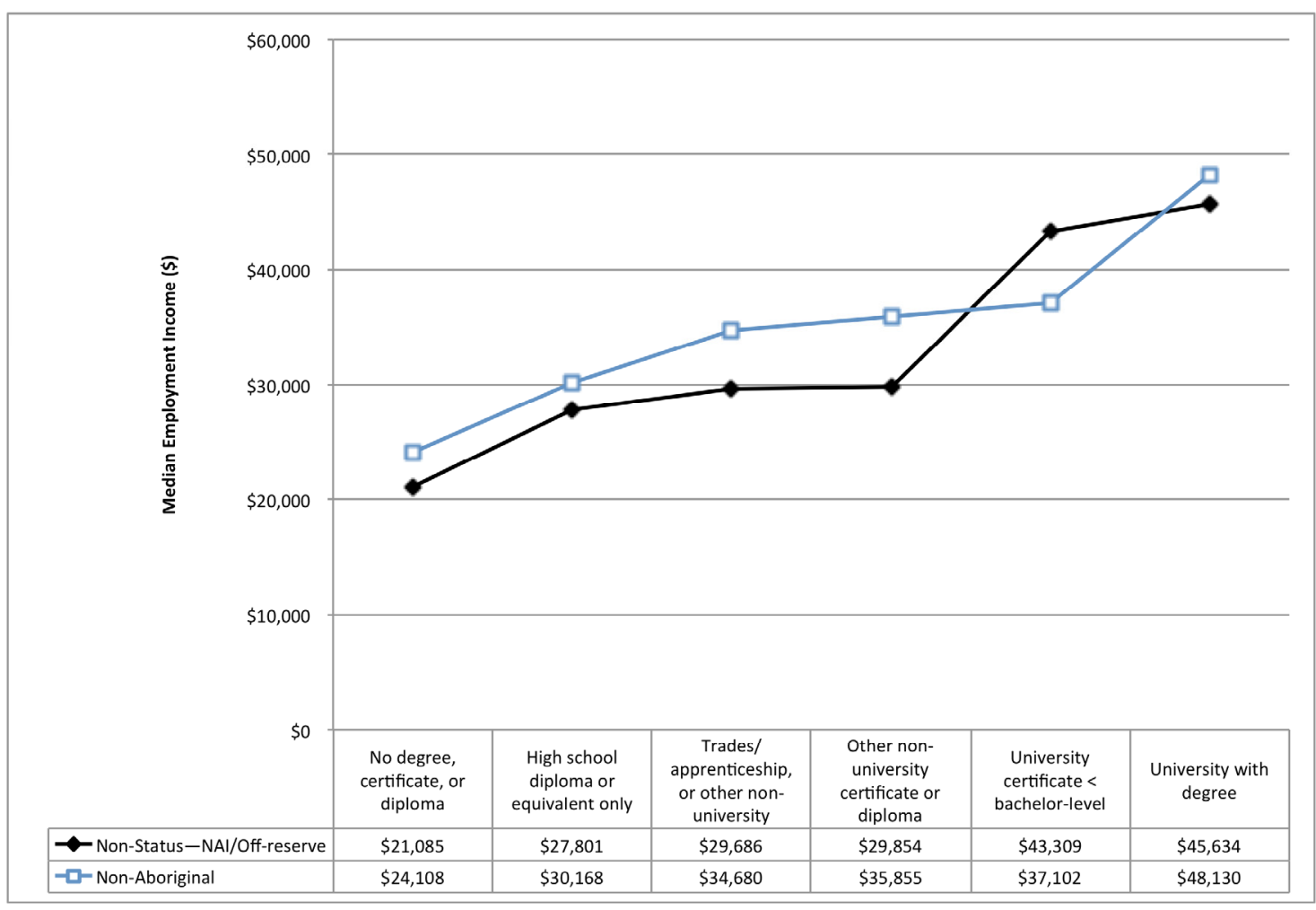


FIGURE 13: Median Employment Income for Non-Status and Non-Aboriginal Youth Aged 18-24 by Highest Level of Schooling, Off-Reserve, 2006

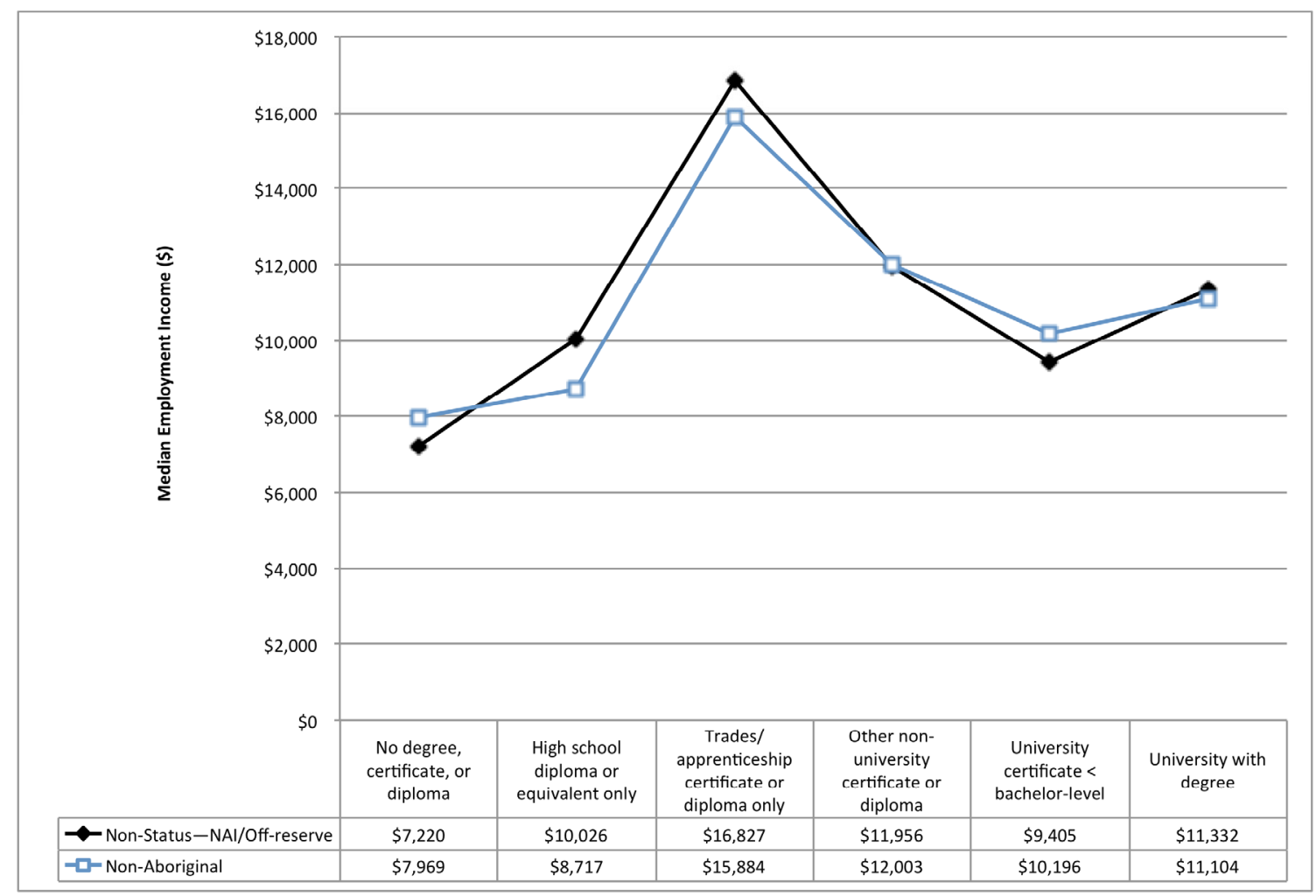

\section{Household and Housing Conditions}

The proportion of households that are headed by lone parents was not significantly higher in the Non-Status Indian (11.5\%) than the non-Aboriginal population (10\%) in 2006 (Figure 14). On the housing front, a much higher percentage of Non-Status Indian (45.0\%) than non-Aboriginal (30.9\%) households rent rather than own their dwelling units (Figure 15). The dwelling units in which Non-Status Indian households live are more likely to need repairs than the dwelling units in which non-Aboriginal people live. Twice as many $(12.1 \%)$ of the dwelling units owned by Non-Status Indians need repairs as those owned by non-Aboriginal people (6\%). Of units rented by Non-Status Indians, 17 percent need repairs, as compared to 9.2 percent of units rented by non-Aboriginal households. Nearly 83 percent of dwellings owned or rented by Non-Status Indians are fifteen years or older in construction, compared to about 78 percent of dwellings owned or rented by nonAboriginal people. 
FIGURE 14: Percentage of Non-Status Indian and Non-Aboriginal Households by Household Type, Off-Reserve, 2006

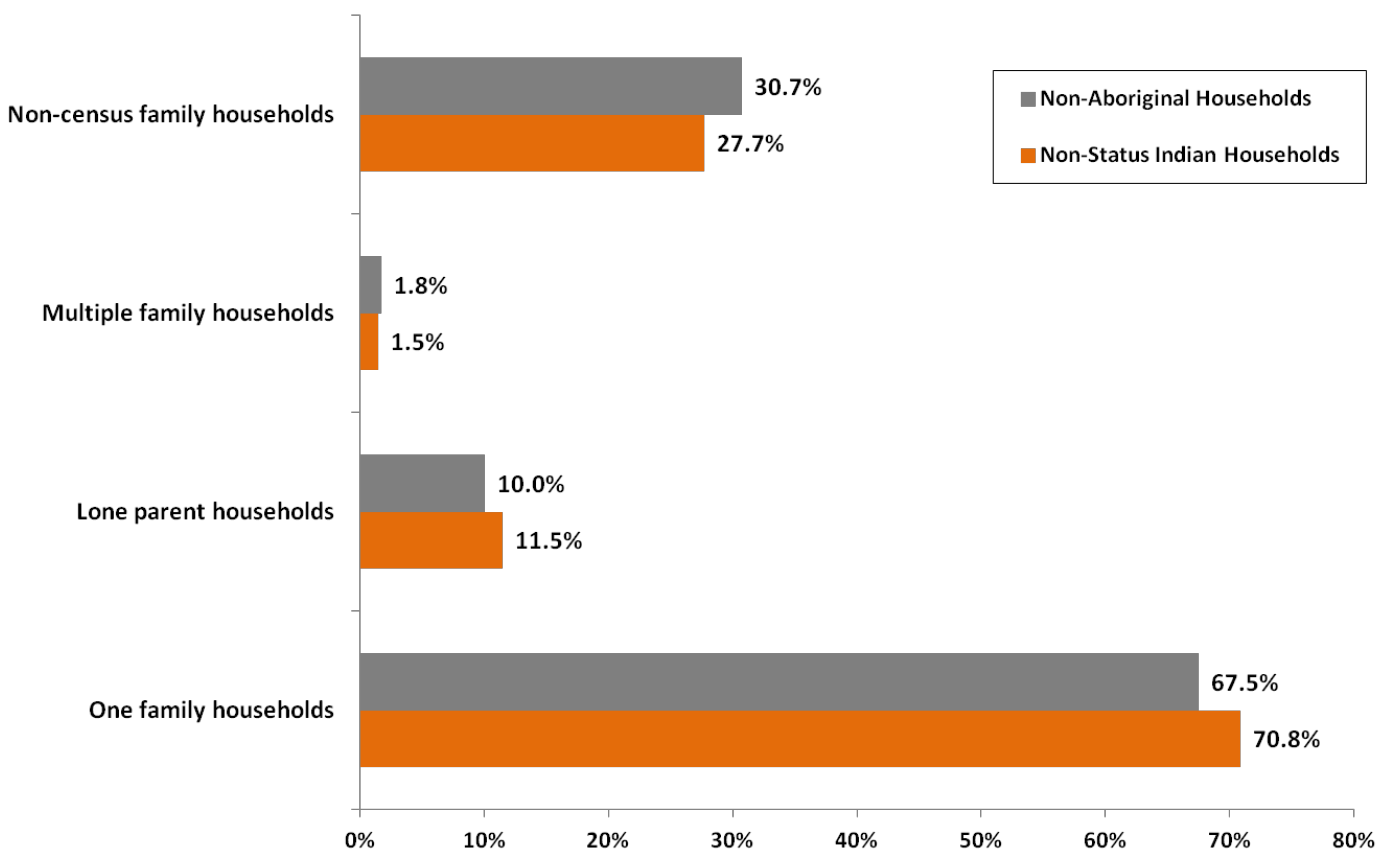

FIGURE 15: Non-Status Indian and Non-Aboriginal Dwellings by Ownership Type, Repairs Needed, and Period of Construction, Off-Reserve, 2006.

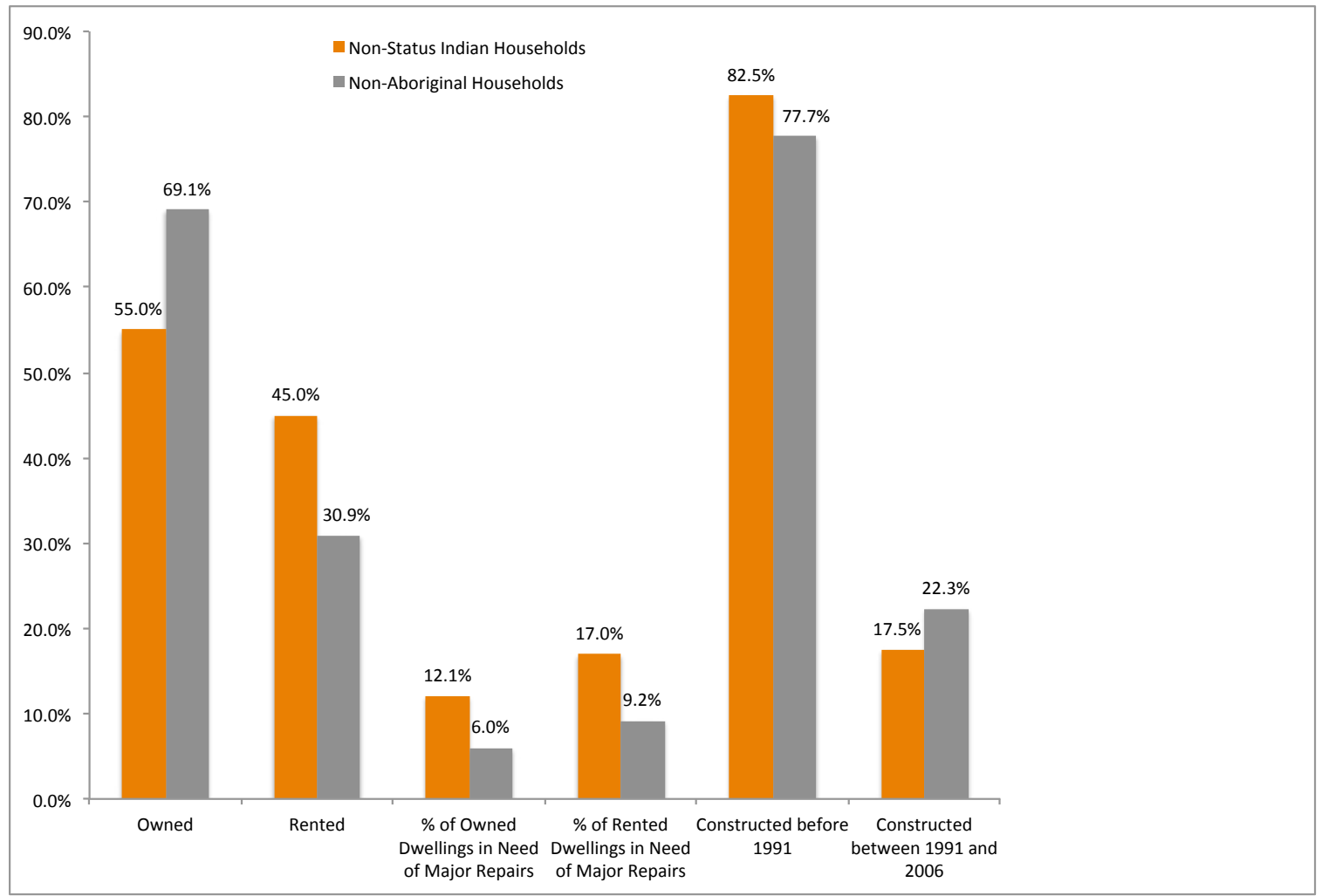




\section{Summary and Conclusions}

Despite differences in legal status and, arguably, in culture and history between NonStatus Indians and other Aboriginal populations, there is very little to differentiate the socio-economic characteristics between the former and the latter. The Non-Status Indian population has been one of the fastest growing Aboriginal populations in Canada since the 1996 Census. The Non-Status Indian population has continued to grow since 1996, and more quickly than basic demographic growth components (fertility and mortality) would suggest. Underlying this increase is likely a change in how individuals respond to the categories available on census forms. Non-Status Indians are not evenly distributed across different provinces and growth rates vary as well, suggesting that there are different patterns of identification with census categories in different areas of Canada.

While the socio-economic characteristics of the Non-Status Indian and the total Aboriginal population are similar, there are differences between Non-Status Indians and non-Aboriginal people. While a proxy measure for school dropouts among NonStatus Indian youth aged 15 to19 declined between 1996 and 2006, dropout rates are considerably higher for Non-Status Indians than for non-Aboriginal people. Non-Status Indian employment rates rose between 1996 and 2006, but they still remain considerably lower than those of non-Aboriginal people. There was growth in self-employment in the Non-Status Indian workforce, but this component of the labour force remained low, and was considerably lower than in the non-Aboriginal workforce. Similarly, which there was growth in Non-Status Indian human capital within the so-called "knowledge industries," proportions remained lower than that of the non-Aboriginal population. When Non-Status Indian education levels increase, so do their incomes.

From a household composition and dwelling condition perspective, the Non-Status Indian population has only a slightly higher share of households who are single parent families compared to Non-Aboriginals. However, Non-Status Indian housing tends to be older than that occupied by non-Aboriginal people, is more likely to be rented, and more likely to need major repairs. For the most part, changes between 1996 and 2006 showed that there were improvements in the socio-economic condition of Non-Status Indian people. However, these trends need to be interpreted with caution. First, it is not clear how much of the improvement is related to changes in the composition of the Non-Status Indian population, as new populations are associated with that category over time. Second, for the most part, improvements in the socio-economic characteristics of the non-Aboriginal population outstripped those of the Non-Status Indian population, leaving questions about the extent to which gaps between them are closing. 


\section{Bibliography}

Aboriginal Affairs and Northern Development Canada. 2011. 2011-2012 Report on Plans and Priorities: Demographic Description. Accessed 28 November 2012. http://www. aadnc-aandc.gc.ca/eng/1315424049095/1315424155048.

Aboriginal Affairs and Northern Development Canada. 2010. Fact Sheet-Urban Aboriginal Population in Canada. Accessed 28 November 2012. http://www.aadnc-aandc. gc.ca/eng/1100100014298/1100100014302.

Andersen, C. 2008. "From Nation to Population: The Racialisation of 'Métis' in the Canadian Census." Nations and Nationalism 14 (2): 347-68. http://dx.doi.org/10.1111/j.14698129.2008.00331.x.

Gionet, L. 2009. "Métis in Canada: Selected Findings of the 2006 Census." Canadian Social Trends 87. http://www.statcan.gc.27 /11-008-x/2009001/article/10769-eng.htm.

Goldmann, G. 1993. The Aboriginal Populationand the Census: 120 Years of Information-1871 to 1991. Ottawa: Statistics Canada.

Goldmann, G. and A. Siggner. 1995. Statistical Concepts of Aboriginal People and Factors Affecting the Counts in the Census and the Aboriginal Peoples Survey. Paper presented to the 1995 Symposium of the Federation of Canadian Demographers, Ottawa.

Guimond, E. 2003. "Fuzzy Definitions and Population Explosion: Changing Identities of Aboriginal Groups in Canada." In Not Strangers in These Parts: Aboriginal People in Cities, ed. D. Newhouse and E. J. Peters, 35-50. Ottawa: Policy Research Initiative.

Guimond, E., N. Robitaille and S. Senécal. 2009. "Aboriginal Populations in Canadian Cities: Why Are They Growing So Fast?" Canadian Issues (Winter): 11-17.

Laliberte, R.F. 2013. "Being Métis: Exploring the Construction, Retention, and Maintenance of Urban Métis Identity." In Indigenous in the City: Contemporary Identities and Cultural Innovation, ed. E.J. Peters and C. Andersen 110-31. Vancouver: UBC Press.

Nagel, J. 1995. "American Indian ethnic renewal: Politics and the resurgence of identity." American Sociological Review 60: 947-65. http://dx.doi.org/10.2307/2096434.

Norris, M.J., and S. Clatworthy. 2003. "Aboriginal Mobility and Migration within Urban Canada: Outcomes, Factors and Implications." In Not Strangers in These Parts: Aboriginal People in Cities, ed. D. Newhouse and E. J. Peters, 51-78. Ottawa: Policy Research Initiative.

Statistics Canada. 2008. Aboriginal Peoples in Canada in 2006: Inuit, Métis and First Nations, 2006 Census. Catalogue no. 97-558-XIE. Accessed 28 November 2012. http://www12.statcan.ca/census-recensement/2006/as-sa/97-558/pdf/97-558XIE2006001.pdf

Siggner, A. J. 2003. "The Challenge of Measuring the Demographic and Socio-Economic Condition of the Urban Aboriginal Population." In Not Strangers in These Parts: Aboriginal People in Cities, ed. D. Newhouse and E. J. Peters, 119-30. Ottawa: Policy Research Initiative. 
Siggner, A. and Hagey, J. 2003. "Measuring the Demographic and Socio-Economic Conditions of Aboriginal Peoples in Canada using the 2001 Census." Prepared for the Canadian Population Society Annual Meetings, Halifax.

UN Statistics Division. n.d. Demographic and Social Statistics, Canadian Census 2006. Accessed 27 November 2012. http://unstats.un.org/unsd/demographic/sources/ census/censusquest.htm\#C. 